\title{
Induction of Metallothionein Gene by Laminin in Normal and Malignant Human Prostate Epithelial Cells
}

Mee Sun Ock ${ }^{1}$ and Hee-Jae Cha ${ }^{1,2_{*}}$

${ }^{1}$ Department of Parasitology and Gnenetics, ${ }^{2}$ Institute for Medical Science, Kosin University College of Medicine, Busan 602-703, Korea

Received December 23, 2010 / Accepted December 30, 2010

\begin{abstract}
Metallothioneins (MT) are a group of low-molecular weight, cysteine-rich, intracellular proteins that are encoded by a family of genes containing at least 10 functional isoforms in human. The expression and induction of these proteins is associated with protection against DNA damage, oxidative stress, and apoptosis. Many studies have shown increased expression of MT in various human tumors, whereas MT is down-regulated in certain tumors such as hepatocellular carcinoma and liver adenocarcinoma. Hence, the expression of MT is not universal to all human tumors but may depend on the differentiation status and proliferative index of tumors, along with other tissue factors and gene mutations. Using Northern blot analysis, we found that laminin induced expression of MT-1 in HSG and PC12 cells, which can be differentiated by laminin, but had no effect on MB-231, MDA-435, and PC-3 cells, which cannot be differentiated by laminin. In addition, we analyzed the expression level of the MT-1 gene in five prostate cancer cell lines possessing different metastatic potential. The expression of MT-1 in normal and less malignant cells (RWPE-1 and WPE1-NA22) was high and up-regulated by laminin, whereas the expression of MT-1 in WPE1-NB14, WPE1-NB11, and WPE1-NB26 cells (malignant) was extremely low and not elevated by laminin. These results suggest that the MT-1 gene is involved in laminin-mediated differentiation and affects the metastatic potential of tumor cells.
\end{abstract}

Key words : Metallothionein, laminin, prostate cancer, differentiation, malignant

\section{서 론}

Metallothioneins (MT)는 세포 내에 존재하는 작은 분자량의 cysteine이 많은 단백질로 인간에서 10 가지 이상의 아형이 존재 하는 것으로 보고되고 있다[6]. MT는 금속과 결합하는 능력을 지니고 있으며 DNA 손상, 산화적인 스트레스나 세포사멸기 작으로부터 세포를 보호하는 것과 밀접한 관계가 있다고 알려 져 있다[6]. 최근의 연구결과로는 MT가 특정 전사유도인자의 아연에 작용하여 전사인자의 활성화에 영향을 끼칠 것으로 보고 되었으며[26] 세포질 내에 존재하던 MT가 세포의 증식과 분화과정에서 핵으로 이동하는 것이 관찰되어 전사유도작용 에 관여 할 것으로 보고된 바 있다[19]. 여러 암에서 MT의 발현 에 관해 많은 연구가 되어 있는데 유방(breast), 대장(colon), 신장(kidney), 간(liver), 폐(lung), 코인두(nasopharynx), 난소 (ovary), 전립선(prostate), 침샘(salivary gland), 정소(testes), 갑상샘(thyroid), 방광(urinary bladder)에서 형성된 암에서 그 발현이 늘어나는 것이 관찰되었다. 하지만 간암 (hepatocellular carcinoma), 간 선암(liver adenocarcinoma)등 몇몇 암에서는 그 발현이 낮아지는 것이 관찰되었으며 $\mathrm{MT}$ 의 발현은 암의 종류 및 분화 상태, 증식 능력에 따라 다른 것으로

*Corresponding author

Tel : +82-51-990-6428, Fax : +82-51-990-3081

E-mail : hcha@kosin.ac.kr
보고되고 있다[6].

라미닌(laminin)은 기저막(basement membrane) 당 단백질 (glycoproteins)의 일종으로 외피세포와 내피세포의 결합, 이 동, 증식 및 분화에 중요한 역할을 하는 단백질로서 15 종 이상 의 다른 isoform이 존재하는 것으로 보고되고 있다[8,13]. 이중 라미닌-1은 인간 침샘세포(human salivary gland cell line, HSG)의 샘꽈리 유사 형태(acinar-like structures)로 형태적 분 화를 유도하며 PC-12 세포를 신경으로 분화 유도시키는 것으 로 보고되고 있다[10]. 라미닌-1에 의한 HSG 세포의 분화유도 과정에서 마이크로어레이 분석을 실시한 결과 MT 유전자가 분화과장에서 과다 발현되는 것이 관찰되었으며 이를 노던블 럿으로 분석하였을 때 라미닌-1 처리 6시간 전후로 5 배에서 10 배의 MT 유전자가 증폭됨이 관찰되었다[11].

전립선 외피 세포주인 RWPE-1 세포의 경우 메트리젤 (matrigel)을 사용한 3D 배양을 실시하면 샘꽈리(acini) 유사형 태로 분화가 유도되는 반면 악성 전립선 암세포주인 WPE1-NB26의 경우 이러한 샘꽈리 형태의 분화가 진행되지 않는 것이 관찰되었다[3]. 라미닌-1 항체로 이러한 전립선 유 래 정상 세포의 샘꽈리 형태 분화가 농도의존적으로 저해하는 결과를 통해 라미닌-1이 전립선 유래 세포의 샘꽈리 형태 분화 에 관여하는 것이 보고되었으며 악성화된 전립선 암 세포에서 는 라미닌-1에 의한 분화 능력이 상실되었음이 밝혀 졌다[3]. 본 연구에서는 악성화 정도가 다른 5 종류의 인간 전립선 세포 
및 암세포에서 라미닌-1에 의해 MT유전자의 발현 유도현상이 어떻게 차이가 나는가를 조사함으로 MT 유전자가 라미닌-1에 의한 분화 유도와 관련이 있는지를 조사하고자 하였다. 더불 어 MT 유전자의 라미닌-1에 의한 유도와 암세포의 악성 정도 의 상관성을 조사하여 $\mathrm{MT}$ 유전자의 암화 과정에서의 역할을 조사하고자 하였다.

\section{재료 및 방법}

\section{세포배양}

HSG 세포는[21] 5\% fetal bovine serum이 첨가된 DMEM/Ham's F-12 (1:1) (Invitrogen, Carlsbad, CA, USA). 에 100 units $/ \mathrm{ml}$ penicillin와 $100 \mathrm{\mu g} / \mathrm{ml}$ streptomycin (Invitrogen, Carlsbad, CA, USA)을 첨가한 배지에서 배양하 였다[13]. PC-12 세포는 10\% fetal bovine serum이 포함된 DMEM에 100 units/ml penicillin와 $100 \mu \mathrm{g} / \mathrm{ml}$ streptomycin 을 첨가한 배지에서 배양하였다[10]. 유방암 세포인 MDA-231, MDA-435 세포와 전립선 암인 PC-3는 $10 \%$ fetal bovine serum이 포함된 RPMI1640에 100 units/ml penicillin와 $100 \mu \mathrm{g}$ $/ \mathrm{ml}$ streptomycin을 첨가한 배지에서 배양하였다 $[1,16]$.

악성화 정도가 다른 다섯 종류의 전립선 세포 및 암세포인 RWPE-1, WPE1-NA22, WPE1-NB14, WPE1-NB11, WPE1-NB26는 complete KSFM 배지[4] (K-SFM 배지에 50 $\mathrm{mg} / \mathrm{ml}$ bovine pituitary extract (BPE), $5 \mathrm{ng} / \mathrm{ml}$ epidermal growth factor (EGF)와 1\% antibiotic/antimycotic mixture (PSF)를 첨가한 배지) (Invitrogen, Carlsbad, CA, USA)에서 배양하였다[3]. 각 세포는 라미닌-1이 코팅된 $100 \mathrm{~mm}$ 배양접 시에 1 시간, 4 시간, 16 시간 배양 후 관찰하였다.

\section{Northern blot analysis}

Stratagene사의 RNA mini-prep kit (Stratagene, La Jolla, CA, USA)을 사용하여 각 세포의 total RNA를 분리하였으며 $10 \mu \mathrm{g}$ 의 RNA를 formaldehyde - agarose gel에 전기영동 한 후 Nytran membrane (Schleicher and Schuell, Keene, NH, USA)에 transfer하고 $\left.{ }^{32} \mathrm{P}\right] \mathrm{dCTP}$ 로 표지 된 $\mathrm{MT}$ 유전자의 cDNA probe로 hybridization하여 관찰하였다[5].

\section{결 과}

라미닌-1에 의해 분화가 유도되는 것으로 알려져 있는 HSG 및 PC-12 세포를 대상으로 라미닌-1이 MT 유전자를 유도하는 지를 노던블럿 방법에 의해 조사하였다. 라미닌-1에 의해 HSG 및 PC-12 두 세포에서는 MT 유전자의 발현이 1시간 처리 후부 터 증가하기 시작하여 4 시간 처리 시 최고를 이루며 16시간 처리 시에는 원래의 수준으로 감소하는 것이 관찰되었다(Fig. 1). 반면 분화 역량을 지니지 않은 암세포인 유방암(MDA-231,
Time of laminin treatment (hr)
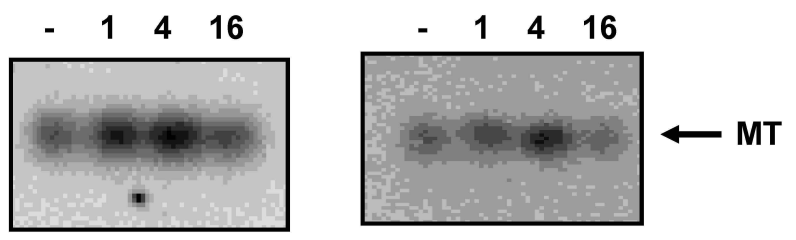

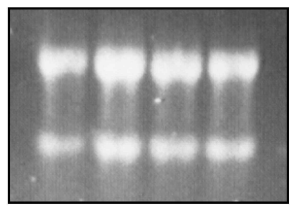

HSG

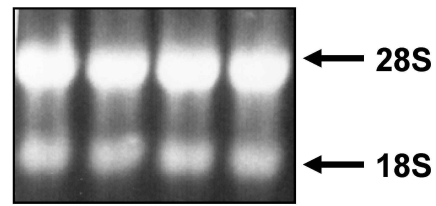

PC-12
Fig. 1. Expression of MT in cultured HSG and PC-12 cell lines treated with laminin-1. Northern blot analysis was conducted to analyze the expression of MT in HSG and PC-12 cells treated with laminin-1 for 1, 4, and $16 \mathrm{hr}$. The amount of total RNA in all lanes was almost the same and was confirmed with $28 \mathrm{~S}$ and $18 \mathrm{~S}$ RNA (bottom panel).

MDA-435) 세포와 전립선 암인 PC-3 세포에서는 라미닌-1의 처리가 $\mathrm{MT}$ 유전자의 변화에 영향을 미치지 못하는 것이 관찰 되었다(Fig. 2). 이러한 결과를 통해 라미닌-1은 정상적인 세포 의 분화유도를 일으키며 라미닌-1에 의해 분화가 유도될 때 MT 단백질의 발현이 증가하며 라미닌-1에 의해 분화가 유도 되지 않는 암세포의 경우 MT 유전자의 발현 역시 유도되지 않는 것으로 추정할 수 있었다.

라미닌-1에 의해 분화가 유도되는 현상 및 이에 따른 MT 유전자의 발현증가가 암의 전이 능력 및 악성화와 관계가 있

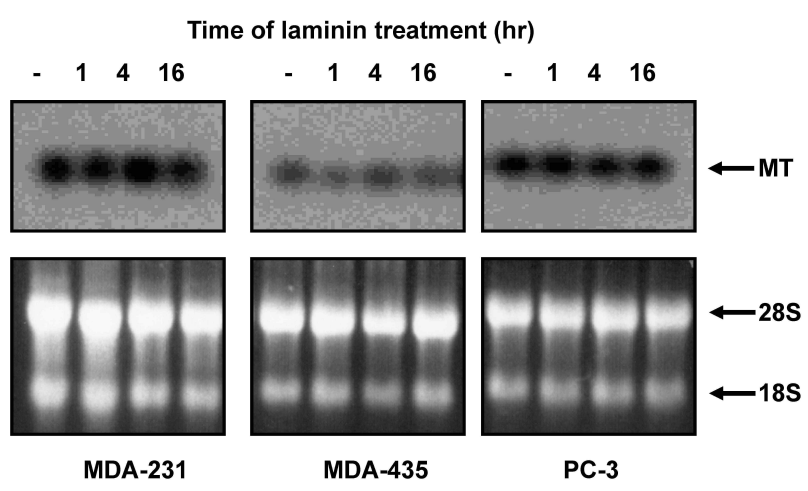

Fig. 2. Expression of MT in cultured breast cancer (MDA-231 and MDA-435) and prostate cancer (PC-3) cell lines treated with laminin-1. Northern blot analysis was conducted to analyze the expression of MT in MDA-231, MDA-435 and PC-3 cells treated with laminin-1 for 1 , 4 , and $16 \mathrm{hr}$. The amount of total RNA in all lanes was almost the same and was confirmed with $28 \mathrm{~S}$ and $18 \mathrm{~S}$ RNA (bottom panel). 


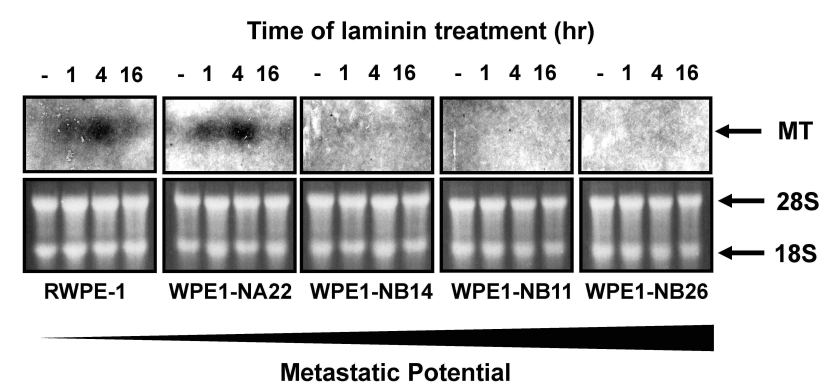

Fig. 3. Expression of MT in cultured prostate epithelial cells (RWPE-1) and prostate cancer cells (WPE1-NA22, WPE1-NB14, WPE1-NB11, and WPE1-NB26) treated with laminin-1. Northern blot analysis was conducted to analyze the expression of MT in RWPE-1, WPE1NA22, WPE1-NB14, WPE1-NB11, and WPE1-NB26 cells treated with laminin-1 for 1,4 , and $16 \mathrm{hr}$. The amount of total RNA in all lanes was almost the same and was confirmed with $28 \mathrm{~S}$ and 18S RNA (bottom panel).

는지를 관찰하기 위해 정상에서부터 전이 및 악성 정도가 다 른 5가지 종류의 전립선 암을 대상으로 라미닌-1에 의한 MT 유전자의 발현 변화를 관찰하였다. 정상적인 전립선 외피세포 인 RWPE-1과 전이 및 악성화가 낮은 WPE1-NA22의 경우 HSG 및 PC-12 세포와 유사하게 라미닌 처리 1시간부터 MT 유전자의 발현이 증가하기 시작하여 4시간 처리 시 최고를 이루며 16 시간째에는 감소하는 것이 관찰되었다. 하지만 전이 능력 및 악성화 정도가 높은 WPE1-NB14, WPE1-NB11, 및 WPE1-NB26에서는 라미닌-1의 처리에도 MT 유전자의 발현 이 증가하지 않는 것이 관찰되었다. 이러한 결과를 통해 라미 닌-1은 정상 세포의 분화를 유도하며 이에 따라 MT 유전자를 유도하며 분화가 유도되지 않는 악성 암에서는 MT 유전자의 발현이 유도되지 않는 것으로 밝혀졌다.

\section{고 찰}

기저막은 얇은 세포외기질(extracellular matrix) 층으로 구 성되어 있으며 많은 성분들이 생물학적으로 중요한 작용을 담당하고 있다[14,15]. 이러한 기저막 층의 세포외기질 단백질 에는 파이브로넥틴, 타입 4 콜라겐, 라미닌 등 여러 단백질들 로 이루어 져 있는데 이 중 하나인 라미닌-1은 $800 \mathrm{kDa}$ 의 당 단백질(glycoprotein)로 암을 이용하여 인위적으로 만들어진 기저막 성분인 메트리젤의 주요 성분 중의 하나로 알려져 있 다[22,23]. 라미닌-1은 많은 기능들이 알려져 있는데 세포 간의 결합, 이동, 증식, 분화, 신경돌기의 성장 및 암의 성장에 영향 을 미치는 것으로 보고되고 있다[18]. 라미닌-1의 여러 기능 중 발생에 미치는 영향을 보면 라미닌-1은 배아 발생과정에 처음으로 합성되는 세포외기질 단백질로 특히 선(glandular) 의 발달에 중요한 역할을 담당하는 것으로 보고되어 있다 $[18,25]$. 침샘세포인 $\mathrm{HSG}$ 의 및 전립선 상피세포가 세포외기질
인 메트리젤에 의해 샘꽈리 형태로 분화되고 이러한 현상이 라미닌-1을 저해하는 라미닌-1 항체를 처리하였을 때 억제되 는 것은 라미닌-1이 이러한 분화 활동에 중요한 역할을 담당하 는 것을 입증해준다[12,24].

라미닌-1에 의한 분화활동에서 중요한 역할을 하는 유전자 를 찾기 위해 라미닌-1에 의한 침샘 세포 분화 유도 과정의 유전자 프로파일을 조사한 결과 $\mathrm{MT}$ 유전자가 특이하게 증가 되는 것이 관찰되었다[11]. 실제 MT 단백질은 포유류 발생과 정에 초기에 발현되는 것이 면역화학기법 연구를 통해 밝혀졌 으며[2] 발생초기 태아의 간, 소장, 이자, 신장 등에서 발현이 관찰되었다 $[7,9,20]$. 최근 여러 연구들이 MT 등에 의한 금속 조절하는 기능이 세포의 분열이나 분화현상에 중요한 역할을 담당할 것으로 시사되고 있으며[6,17] 이러한 결과들을 통해 세포 증식 및 분화에 MT 단백질이 중요한 역할을 담당할 가능 성을 추정할 수 있다. 세포의 증식과 분화는 암의 악성화 및 grade에도 밀접한 연관이 있다. 악성 암은 정상세포에 비해 분화 유도가 되지 않고 증식이 촉진되는 특징을 지니고 있으 며 이러한 암을 강제로 분화를 유도하여 암을 치료하고자 하 는 연구가 이루어 지고 있다. 따라서 MT 단백질의 발현 양상 과 라미닌-1 등에 의한 분화유도능력은 암의 악성 단계와 밀접 한 연관이 있을 수 있으며 본 과제에서는 전이 능력이 다른 5 종류의 전립선 상피 및 전립선 암 세포에서 라미닌-1에 의한 MT 유전자의 발현을 조사 함으로서 이러한 상관관계를 밝히 고자 하였다. 라미닌-1에 의해 꽈리샘으로 분화가 가능한 정상 세포인 RWPE-1 및 악성화 정도가 낮은 WPE1-NA22에서는 $\mathrm{MT}$ 유전자가 라미닌-1에 의해 유도되는 반면 분화가 유도되 지 않는 악성 암인 WPE1-NB14, WPE1-NB11, WPE1-NB26에 서는 라미닌-1에 의해 MT 유전자가 유도되지 않았으며 이러 한 결과를 통해 전립선 암의 악성화는 분화유도 가능성 및 분화 유도에 따른 $\mathrm{MT}$ 유전자 발현과 밀접한 연관이 있음을 확인하였다.

\section{감사의 글}

본 연구는 2010년도 고신대학교 의과대학 의과학연구소 학 술연구비의 지원에 의해 수행되었음.

\section{References}

1. Alimirah, F., J. Chen, Z. Basrawala, H. Xin, and D. Choubey. 2006. DU-145 and PC-3 human prostate cancer cell lines express androgen receptor: implications for the androgen receptor functions and regulation. FEBS Lett. 580, 2294-2300.

2. Andrews, G. K., E. D. Adamson, and L. Gedamu. 1984. The ontogeny of expression of murine metallothionein: comparison with the alpha-fetoprotein gene. Dev. Biol. 103, 294-303.

3. Bello-DeOcampo, D., H. K. Kleinman, N. D. Deocampo, and 
M. M. Webber. 2001. Laminin-1 and alpha6beta1 integrin regulate acinar morphogenesis of normal and malignant human prostate epithelial cells. Prostate 46, 142-153.

4. Bello, D., M. M. Webber, H. K. Kleinman, D. D. Wartinger, and J. S. Rhim. 1997. Androgen responsive adult human prostatic epithelial cell lines immortalized by human papillomavirus 18. Carcinogenesis 18, 1215-1223.

5. Cha, H. J., M. J. Jeong, and H. K. Kleinman. 2003. Role of thymosin beta4 in tumor metastasis and angiogenesis. J. Natl. Cancer Inst. 95, 1674-1680.

6. Cherian, M. G., A. Jayasurya, and B. H. Bay. 2003. Metallothioneins in human tumors and potential roles in carcinogenesis. Mutat. Res. 533, 201-209.

7. Clarkson, J. P., M. E. Elmes, B. Jasani, and M. Webb. 1985. Histological demonstration of immunoreactive zinc metallothionein in liver and ileum of rat and man. Histochem $J$. 17, 343-352.

8. Colognato, H. and P. D. Yurchenco. 2000. Form and function: the laminin family of heterotrimers. Dev. Dyn. 218, 213-234.

9. Danielson, K. G., S. Ohi, and P. C. Huang. 1982. Immunochemical detection of metallothionein in specific epithelial cells of rat organs. Proc. Natl. Acad Sci. USA 79, 2301-2304.

10. Graner, E., A. F. Mercadante, S. M. Zanata, V. R. Martins, D. G. Jay, and R. R. Brentani. 2000. Laminin-induced PC-12 cell differentiation is inhibited following laser inactivation of cellular prion protein. FEBS Lett. 482, 257-260.

11. Hecht, D., D. Jung, V. V. Prabhu, P. J. Munson, M. P. Hoffman, and H. K. Kleinman. 2002. Metallothionein promotes laminin-1-induced acinar differentiation in vitro and reduces tumor growth in vivo. Cancer Res. 62, 5370-5374.

12. Hoffman, M. P., M. C. Kibbey, J. J. Letterio, and H. K. Kleinman. 1996. Role of laminin-1 and TGF-beta 3 in acinar differentiation of a human submandibular gland cell line (HSG). J. Cell Sci. 109, 2013-2021.

13. Hoffman, M. P., M. Nomizu, E. Roque, S. Lee, D. W. Jung, Y. Yamada, and H. K. Kleinman. 1998. Laminin-1 and laminin-2 G-domain synthetic peptides bind syndecan-1 and are involved in acinar formation of a human submandibular gland cell line. J. Biol. Chem 273, 28633-28641.

14. Kleinman, H. K., M. L. McGarvey, J. R. Hassell, V. L. Star, F. B. Cannon, G. W. Laurie, and G. R. Martin. 1986. Basement membrane complexes with biological activity.
Biochemistry 25, 312-318

15. Kleinman, H. K., M. L. McGarvey, L. A. Liotta, P. G. Robey, K. Tryggvason, and G. R. Martin. 1982. Isolation and characterization of type IV procollagen, laminin, and heparan sulfate proteoglycan from the EHS sarcoma. Biochemistry 21, 6188-6193.

16. Lee, J. H. and D. R. Welch. 1997. Suppression of metastasis in human breast carcinoma MDA-MB-435 cells after transfection with the metastasis suppressor gene, KiSS-1. Cancer Res. 57, 2384-2387.

17. Lichtlen, P. and W. Schaffner. 2001. Putting its fingers on stressful situations: the heavy metal-regulatory transcription factor MTF-1. Bioessays 23, 1010-1017.

18. Malinda, K. M. and H. K. Kleinman. 1996. The laminins. Int. J. Biochem Cell Biol. 28, 957-959.

19. Nartey, N., M. G. Cherian, and D. Banerjee. 1987. Immunohistochemical localization of metallothionein in human thyroid tumors. Am J. Pathol. 129, 177-182.

20. Nishimura, H., N. Nishimura, and C. Tohyama. 1989. Immunohistochemical localization of metallothionein in developing rat tissues. J. Histochem Cytochem 37, 715-722.

21. Shirasuna, K., M. Sato, and T. Miyazaki. 1981. A neoplastic epithelial duct cell line established from an irradiated human salivary gland. Cancer 48, 745-752.

22. Timpl, R. and J. C. Brown. 1994. The laminins. Matrix Biol. 14, 275-281.

23. Timpl, R., H. Rohde, P. G. Robey, S. I. Rennard, J. M. Foidart, and G. R. Martin. 1979. Laminin--a glycoprotein from basement membranes. J. Biol. Chem 254, 9933-9937.

24. Weaver, V. M., A. H. Fischer, O. W. Peterson, and M. J. Bissell. 1996. The importance of the microenvironment in breast cancer progression: recapitulation of mammary tumorigenesis using a unique human mammary epithelial cell model and a three-dimensional culture assay. Biochem Cell Biol. 74, 833-851.

25. Webber, M. M., D. Bello, H. K. Kleinman, and M. P. Hoffman. 1997. Acinar differentiation by non-malignant immortalized human prostatic epithelial cells and its loss by malignant cells. Carcinogenesis 18, 1225-1231.

26. Zeng, J., B. L. Vallee, and J. H. Kagi. 1991. Zinc transfer from transcription factor IIIA fingers to thionein clusters. Proc. Natl. Acad Sci. USA 88, 9984-9988. 
초록 : 악성 단계별 인간 전립선 암세포에서 라미닌에 의한 metallothionein 유전자 발현유도 현상 연구 옥미선 ${ }^{1} \cdot$ 차희재 $^{1,2} \star$

( ${ }^{1}$ 고신대학교 의과대학 기생충학 유전학 교실, ${ }^{2}$ 고신대학교 의과대학 의과학 연구소)

라미닌-1에 의해 분화가 유도되는 것으로 알려져 있는 HSG 및 PC-12에서는 라미닌-1에 의해 MT 유전자의 발현이 유도되었지만 반면 분화 역량을 지니지 않은 암세포인 유방암(MDA-231, MDA-435) 세포와 전립선 암인 PC-3 세포에서는 라미닌-1의 처리가 MT 유전자의 변화에 영향을 미치지 못하는 것이 관찰되었다. 라미닌-1에 의해 분화가 유도되는 현상 및 이에 따른 MT 유전자의 발현증가가 암의 전이 능력 및 악성화와 관계가 있는지를 관찰하기 위해 정상에서부터 전이 및 악성 정도가 다른 5가지 종류의 전립선 암을 대상으로 라미닌-1에 의한 MT 유전자의 발현 변화를 관찰한 결과 정상적인 전립선 외피세포인 RWPE-1과 전이 및 악성화가 낮은 WPE1-NA22 의 경우 라미닌-1에 의해 MT 유전자의 발현이 증가하였으며, 악성화 정도가 높은 WPE1-NB14, WPE1-NB11, 및 WPE1-NB26에서는 라미닌-1의 처리에도 MT 유전자의 발현이 증가하지 않는 것이 관찰되었다. 이러한 결과를 통해 라미닌-1은 정상 세포의 분화를 유도하며 이에 따라 MT 유전자를 유도하며 분화가 유도되지 않는 악성 암 에서는 MT 유전자의 발현이 유도되지 않는 것으로 확인되었다. 